\title{
Impact of irrigated agriculture on groundwater-recharge salinity: a major sustainability concern in semi-arid regions
}

\author{
Stephen Foster ${ }^{1} \cdot$ Antonio Pulido-Bosch $^{2}$ - Ángela Vallejos ${ }^{2} \cdot$ Luis Molina $^{2} \cdot$ Armando Llop $^{3} \cdot$ Alan M. MacDonald $^{4}$
}

Received: 1 February 2018 / Accepted: 5 July 2018 / Published online: 14 July 2018

(C) The Author(s) 2018

\begin{abstract}
Intensive irrigated agriculture substantially modifies the hydrological cycle and often has major environmental impacts. The article focuses upon a specific concern - the tendency for progressive long-term increases in the salinity of groundwater recharge derived from irrigated permeable soils and replenishment of unconfined aquifers in more arid regions. This process has received only scant attention in the water-resource literature and has not been considered by agricultural science. This work makes an original contribution by analysing, from scientific principles, how the salinisation of groundwater recharge arises and identifies the factors affecting its severity. If not proactively managed, the process eventually will impact irrigation waterwell salinity, the productivity of agriculture itself, and can even lead to land abandonment. The types of management measure required for mitigation are discussed through three detailed case histories of areas with high-value groundwater-irrigated agriculture (in Spain, Argentina and Pakistan), which provide a long-term perspective on the evolution of the problem over various decades.
\end{abstract}

Keywords Soil science $\cdot$ Groundwater recharge $\cdot$ Salinization $\cdot$ Irrigation engineering $\cdot$ Groundwater management

\section{Introduction}

\section{Irrigated agriculture and groundwater}

Understanding the impact of irrigated agriculture on the hydrological cycle is critical for effective management of groundwater resources and for promoting more sustainable irrigated agriculture (Seibert et al. 2010; Foster and Shah 2012). Irrigated crop-cultivation practices change the soilwater regime and modify groundwater recharge rates (Foster et al. 2000; Leduc et al. 2001). Where flood irrigation techniques with surface water are practiced on permeable soils, they are a major source of groundwater recharge and often

Stephen Foster

DrStephenFoster@aol.com

University College London, Gower Street, London WC1R 6BT, UK

2 Universidad de Almeria, Almeria, Spain

3 INA Centro de Economia y Legislacion del Agua, Mendoza, Argentina

4 British Geological Survey, Lyell Centre, Edinburgh EH14 4AP, UK the predominant one in arid terrains (Foster and Perry 2009; Jimenez-Martinez et al. 2009).

The impacts of irrigated agriculture on groundwater quality are also profound (Scanlon et al. 2007), with dissolved salts in irrigation water being concentrated by soil evapotranspiration and subsequently leached from permeable soils to groundwater-as so-called 'irrigation return-flow' (the term used by agricultural engineers and scientists for 'irrigation in excess of plant needs' that will drain from the soil and 'return' to groundwater (or surface water) bodies according to the physical properties of the sub-soil profile). The effect is compounded if the irrigation water itself has significant salinity, which may be the case where groundwater or wasterwater is used. On the other hand, irrigation-canal seepage can provide helpful dilution if they carry low-salinity surface water.

In recent years water security concerns have centred on groundwater depletion by withdrawls for irrigated agriculture, and only limited attention has been paid to the more insidious (and more chronic) problem of progressive aquifer salinisation of groundwater recharge by irrigation return-flows, which is occurring in many semi-arid regions (Llop 2002; Foster et al. 2002; Garduno and Foster 2010; Ó Dochartaigh et al. 2010). Analysis of the phenomenon of groundwater recharge salinisation, and its serious long-term implications, is the primary objective of the present report. 
Groundwater salinisation can have various origins (Foster et al. 2000) in addition to the salinisation of groundwater recharge, and it is recognised that other contemporary processes may be either accelerating groundwater salinisation and/or complicating its interpretation (Fig. 1):

- Mobilisation of geogenic salinity from connate water at depth in aquitards or aquifers, due to over-deepening and/ or excessive waterwell pumping

- Intrusion of saline water into aquifers due to inadequatelycontrolled construction and/or operation of irrigation waterwells in coastal areas

- Salinisation as a result of infiltration of reject brines from desalination plants or hydrocarbon exploitation, if discharged to ephemeral (losing) watercourses or seep from retention ponds

- Salinisation from land waterlogging where the water table is very shallow, and accompanied by direct phreatic evaporation with rapid salinisation of shallow groundwater.

Historically, salinisation from land waterlogging has been the focus of major programmes of applied research and is well documented in the agricultural literature, but should not be confused with the mechanism of salinisation of groundwater recharge described here.

\section{Analysis of the recharge salinisation process}

Rain water has very low total dissolved solids (TDS) and slightly acidic $\mathrm{pH}$ - with $\mathrm{Cl}$ and $\mathrm{Na}$ generally in the range 10-20 $\mathrm{mg} / \mathrm{L}$ (although higher in coastal zones due to aerosol effects). On coming into contact with the land surface, rainfall acquires $\mathrm{Ca}$ and $\mathrm{HCO}_{3}$, and commonly reaches 200-500 $\mathrm{mgTDS} / \mathrm{L}$ in natural aquifer recharge. On permeable uncultivated land, the vadose-zone $\mathrm{Cl}$ profile can be used to estimate historic rates of groundwater recharge (Edmunds and Tyler 2002), and seasonal differences in soil-water $\mathrm{Cl}$ content allows calculation of actual evaporation (Bouhlassa et al. 2016).

However, where irrigation techniques are practiced on permeable soils, they exert a major influence on groundwater quality. The dissolved salts in irrigation water are concentrated by evapotranspiration in soil solution and subsequently leached to groundwater. In many cases, while irrigation water is of the $\mathrm{CaHCO}_{3}$ type, irrigationreturn water is of the ' $\mathrm{NaCl}$ type'. In this report, the process has been evaluated using a soil salt-balance approach, and the relative annual salt concentration factor (CF) for groundwater irrigation estimated on this basis. Figure 2 provides an indication of how this factor varies with (so-called) irrigation water-use efficiency $(a)$, crop type and climatic regime, which determine effective rainfall (ER) and the irrigation lamina.

The vertical hydraulic conductivity of the vadose zone then controls the rate of downward penetration of saline returns (at times when the incidence of rainfall and irrigation lead to soil-moisture exceeding natural retention capacity), and thus the time-lag before any deterioration in groundwater quality first becomes evident. The overall level of impact on groundwater quality will be more marked in aquifer systems of low throughflow and limited storage. The precise level of risk, and rate of onset of potential problems will vary widely with hydrogeologic

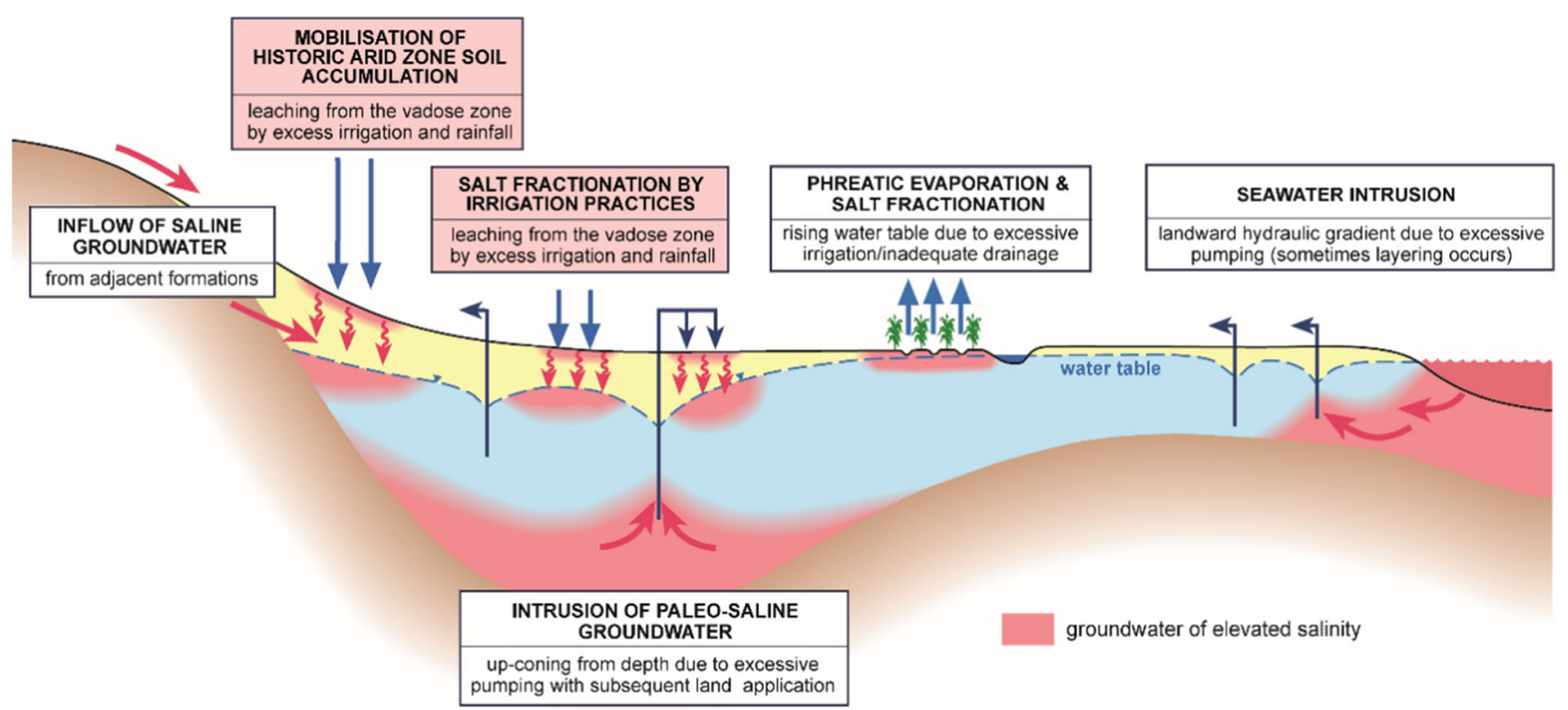

Fig. 1 Schematic overview of common processes of groundwater salinisation 
setting and agronomic practices, with the greatest problems arising where:

- Groundwater supply salinity is augmented by mobilisation of connate water from depth in aquifers or underlying aquitards.

- Major natural salt accumulation in the vadose zone by native vegetation existed prior to the development of irrigated agriculture.

- A high proportion of the aquifer recharge area is under irrigated agriculture.

- The number of days annually that soil moisture is maintained by groundwater irrigation is elevated.

\section{Consequences of groundwater salinisation}

Groundwater with electrical conductivity (EC) $>2,000 \mu \mathrm{S} / \mathrm{cm}$ has been classified as moderately saline for use in crop irrigation (Rhoades et al. 1992) - there is no 'standard conversion' from the readily measured parameter EC to TDS (total dissolved solids or salinity in $\mathrm{mg} / \mathrm{L}$ ), since it varies somewhat with the predominant salts $\left(\mathrm{Na}-\mathrm{Cl}, \mathrm{Ca}-\mathrm{SO}_{4}, \mathrm{Ca}-\mathrm{HCO}_{3}, \mathrm{Mg}-\right.$ $\mathrm{HCO}_{3}$ ) in solution; however, an average conversion factor of $\times 0.65$ is used here. Whilst it is feasible to irrigate with water of EC up to $5,000 \mu \mathrm{S} / \mathrm{cm}(3,250 \mathrm{mgTDS} / \mathrm{L})$ for less sensitive crops (e.g. onions), use on more sensitive crops (e.g. some cereals) will impact their growth and reduce productivity, and seriously damage the most sensitive crops (including many vegetables, fruit trees and grape vines (Shani and Dudley 2001)). Increasing salinity will also reduce the utility of groundwater for public and industrial water supply.

Moreover, soil sodicity often increases with increasing irrigation-water salinity and this can lead to decreasing soil permeability and breakdown of soil structure (Quirk and Schofield 1955). The sodium adsorption ration (SAR) of water, calculated by $\left.\mathrm{SAR}=\mathrm{Na} /[(\mathrm{Ca}+\mathrm{Mg}) / 2)^{1 / 2}\right]$ is an indicator of potential detrimental impact on the permeability of finergrained soils (Hillel et al. 2008) — with a SAR of $>10$ being definitely detrimental to texture and fertility, and values of $3-$ 10 affecting some more sensitive soils and crops. The SAR concept has subsequently been extended by the CROSS (cation ratio of soil structural stability) concept (Rengasamy and Marchuk 2011), which provides a further indication of the hazard of irrigation water with elevated sodic salinity.

\section{Shallow groundwater salinisation: outline of case profiles}

\section{Context of selected cases}

Groundwater salinisation by irrigation return flows is a serious long-term concern for the sustainability of both water
Fig. 2 Estimation of the concentration factor for irrigation return-flow salinity under varying regimes of groundwater irrigation

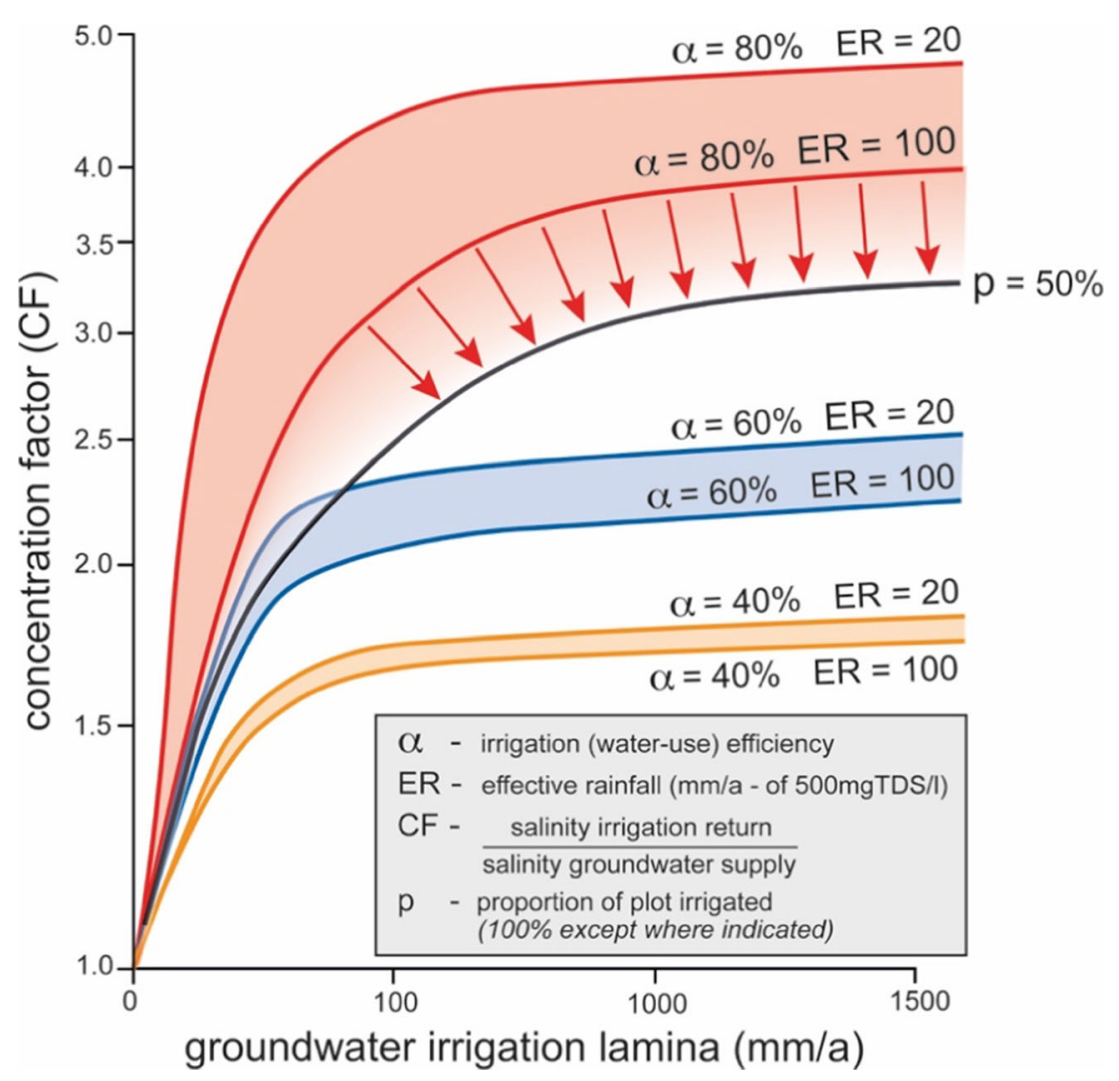


resources and irrigated agriculture (Foster and Cherlet 2014). The three case histories included here provide a long-term (20-40 year) perspective on the evolution of the problem, are widely drawn geographically and cover a wide range of intensive groundwater-fed irrigated agriculture. The groundwater data for each area, which have been compiled in this report, have been obtained from field surveys, monitoring archives and (in the case of the Campo de Dalias, Spain) from published research also. The cases selected are ones in which significant data from field research are available (compared to many other otherwise comparable locations), but even here the lack of systematic long-term monitoring data introduces some constraints on interpretations. It is believed that the process of groundwater recharge salinisation from irrigation water-returns is occurring very widely in the more arid regions with significant irrigated cultivation, but given its slow insidious impact and the generally poor level of field water-quality monitoring, it is not yet widely identified or reported.

\section{Campo de Dalias, Almeria, Spain}

The Campo de Dalias is a somewhat elevated arid coastal plain extending over $300 \mathrm{~km}^{2}$, underlain by a geologically complex aquifer system (Fig. 3). It has an average rainfall of about $260 \mathrm{~mm} / \mathrm{a}$, but the southern flanks of the neighbouring Sierra de Gador mountains are much wetter and high-intensity rainfall events generate flash run-off which naturally recharges the groundwater system (Pulido-Bosch 2005). This arid coastal plain has been progressively transformed by irrigated agriculture, which commenced in 1928 with the introduction of rural electrification and drilling of 40 irrigation waterwells. During 1965-1985 groundwater irrigation expanded rapidly — and today there are more than 1,200 irrigation waterwells with some 20,000 ha (around $65 \%$ ) of the land surface covered by plastic greenhouses, many with 'engineered soils' and hydroponic cultivation. Intensive vegetable cultivation (tomato, pepper, cucumber, eggplant, courgettes, green beans, melon and watermelon), in part for the export market, constitutes an industry with a turnover in excess of $€ 1,200 \mathrm{M} / \mathrm{a}$.

The aquifer system has a complex geometry (Fig. 3), which has been researched in considerable detail in recent years (Pulido-Bosch 2005). In the present context, the main interest is the upper aquifer, which is present over much of the plain and comprises Pliocene calcarenites/conglomerates overlain by Quaternary alluvial outwash fans. This unit is underlain by a thick series of impermeable Pliocene marls containing brackish connate water. The Triassic dolomitic limestone aquifer, which forms most of the neighbouring Sierra de Gador recharge area, extends highly confined at depth beneath most of the Campo de Dalias.

The intensive use of groundwater for irrigation and the presence of such an extensive land area under plastic have completely modified the local groundwater recharge regime (Thompson et al. 2006) with:

- Well-drained 'artificial' greenhouse soils allowing excess irrigation to leach accumulated salts, with about $75 \%$ of farmers applying 30-60 $\mathrm{mm}$ after transplanting crops and a similar lamina in the non-cropping period

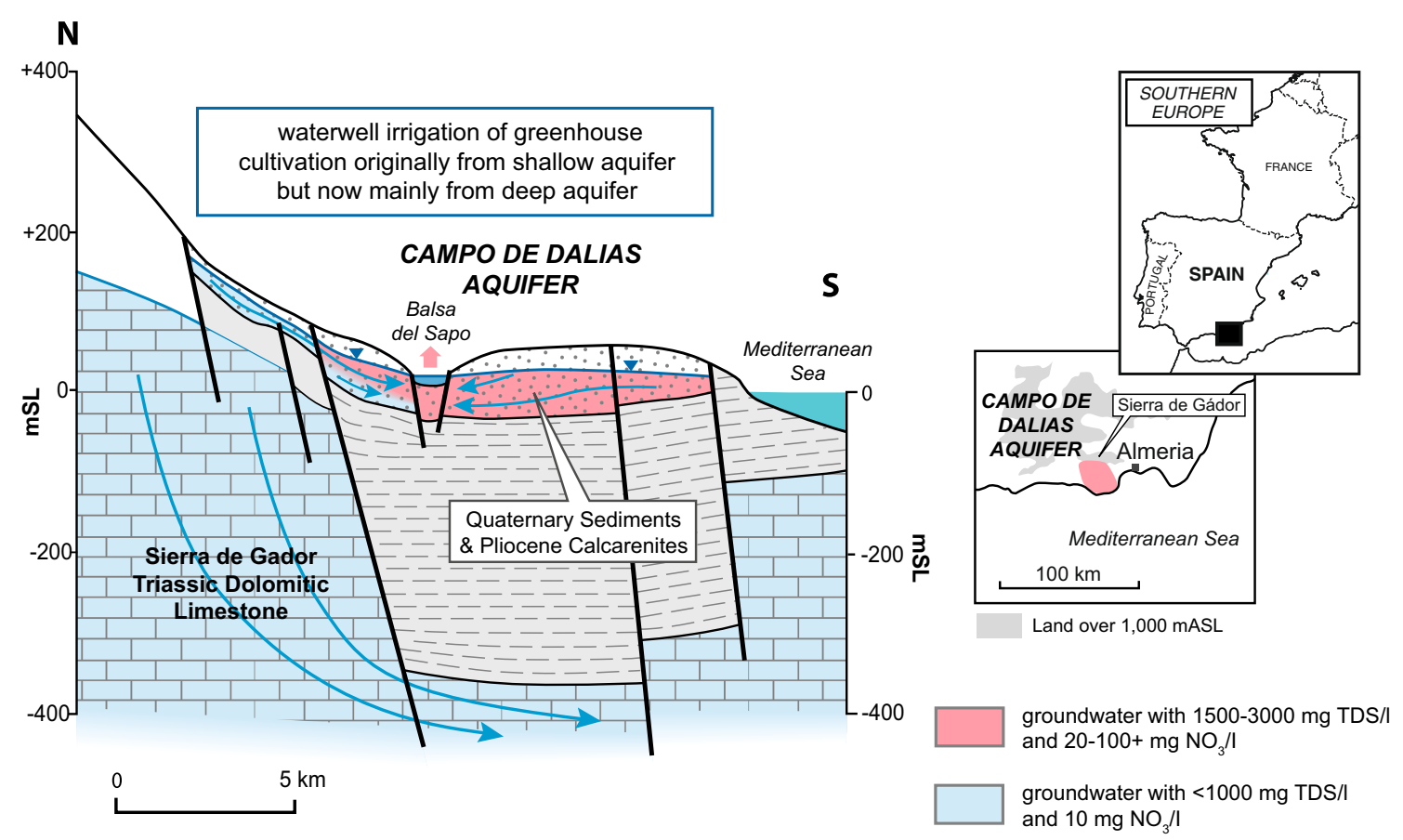

Fig. 3 Hydrogeological cross-section and location map of the Campo de Dalias of Almeria, Spain 
- Rainfall on greenhouses being directed to soakaways from where most infiltrates directly to shallow groundwater

- Large manure applications (2,300-4,600 kgN/ha) applied on greenhouse construction, with a subsequent application (600-1,700 kgN/ha) widely every $2-5$ years and considerable additional ferti-irrigation resulting in high-nitrate irrigation returns to shallow groundwater.

These processes, and high evapotranspiration rates, led to steadily increasing salinity of the upper aquifer, with mobilisation of connate saline water from the underlying Pliocene marls by some deeper irrigation waterwells further aggravating the situation. The result was that by the late $1990 \mathrm{~s}$ the salinity of groundwater in the upper aquifer had increased from $<1,200 \mathrm{mgTDS} / \mathrm{L}$ to $>2,000 \mathrm{mgTDS} / \mathrm{L}$, and in some cases $>3,000 \mathrm{mgTDS} / \mathrm{L}$ (Figs. 3 and 4), causing the abandonment of many shallow waterwells. The presence of elevated groundwater nitrate concentrations (Fig. 4) can be used to trace the penetration of irrigation return-water into the upper aquifer (Pulido-Bosch et al. 2000). In addition to their elevated salinity (1,500-3,500 mg TDS/L), all shallow waterwells yield groundwater with very high nitrate content (50$\left.250 \mathrm{mg} \mathrm{NO}_{3} / \mathrm{L}\right)$ and their stable isotope $\left({ }^{15} \mathrm{~N}\right.$ and $\left.{ }^{18} \mathrm{O}\right)$ composition suggests that most is manure-derived (Pulido-Bosch 2005; Thompson et al. 2013). In contrast, waterwells taking groundwater from the deep (Triassic dolomitic limestone) aquifer, which is derived from recharge in uncultivated mountain zones, have $\mathrm{NO}_{3}<10 \mathrm{mg} / \mathrm{L}$ and $\mathrm{TDS}<1,000 \mathrm{mg} / \mathrm{L}$.

As a result of rising groundwater salinity during the $1990 \mathrm{~s}$, pumping from the upper aquifer reduced from 45 to $10 \mathrm{Mm}^{3} / \mathrm{a}$ and was substituted by increased abstraction from the deep aquifer, which became overexploited with water levels locally depressed to below sea-level. The marked reduction of pumping from the upper aquifer, coupled with irrigation return flows now derived largely from the deep aquifer with lower salinity groundwater, has led to:

- Marked water-table rebound in the upper aquifer (Fig. 4)

- Creation of an aquatic wetland in La Cañada de Las Norias (a neotectonic land-surface depression) known as La Balsa del Sapo, whose water currently has EC > $5,000 \mu \mathrm{S} / \mathrm{cm}$, coupled with persistent inundation of some glasshouse infrastructure and rural dwellings (Molina et al. 2015)

- Some initial signs of the 'freshening-up' of the upper aquifer to 1,500-3,000 $\mathrm{mgTDS} / \mathrm{L}$ (Fig. 4), due to a probable reduction in irrigation-return salinity consequent upon the use of a low salinity groundwater for irrigation $(<1,000$ $\mathrm{mgTDS} / \mathrm{L}$ ) and some artificial recharge from greenhouse drains.

All of the aforementioned interpretations have been corroborated by isotopic data (Vallejos et al. 1997; Diaz-Puga et al. 2016), which reveal that only a few shallow waterwells in piedmont locations record ${ }^{3} \mathrm{H}$ at measurable (post-1965) levels. This suggests that rainfall recharge has mixed with a large volume of older groundwater in the main aquifers, whose $\mathrm{C}$-isotopes suggest an age of more than 1,000 years.

Certain specific groundwater management measures are worthy of detailed consideration to mitigate groundwater
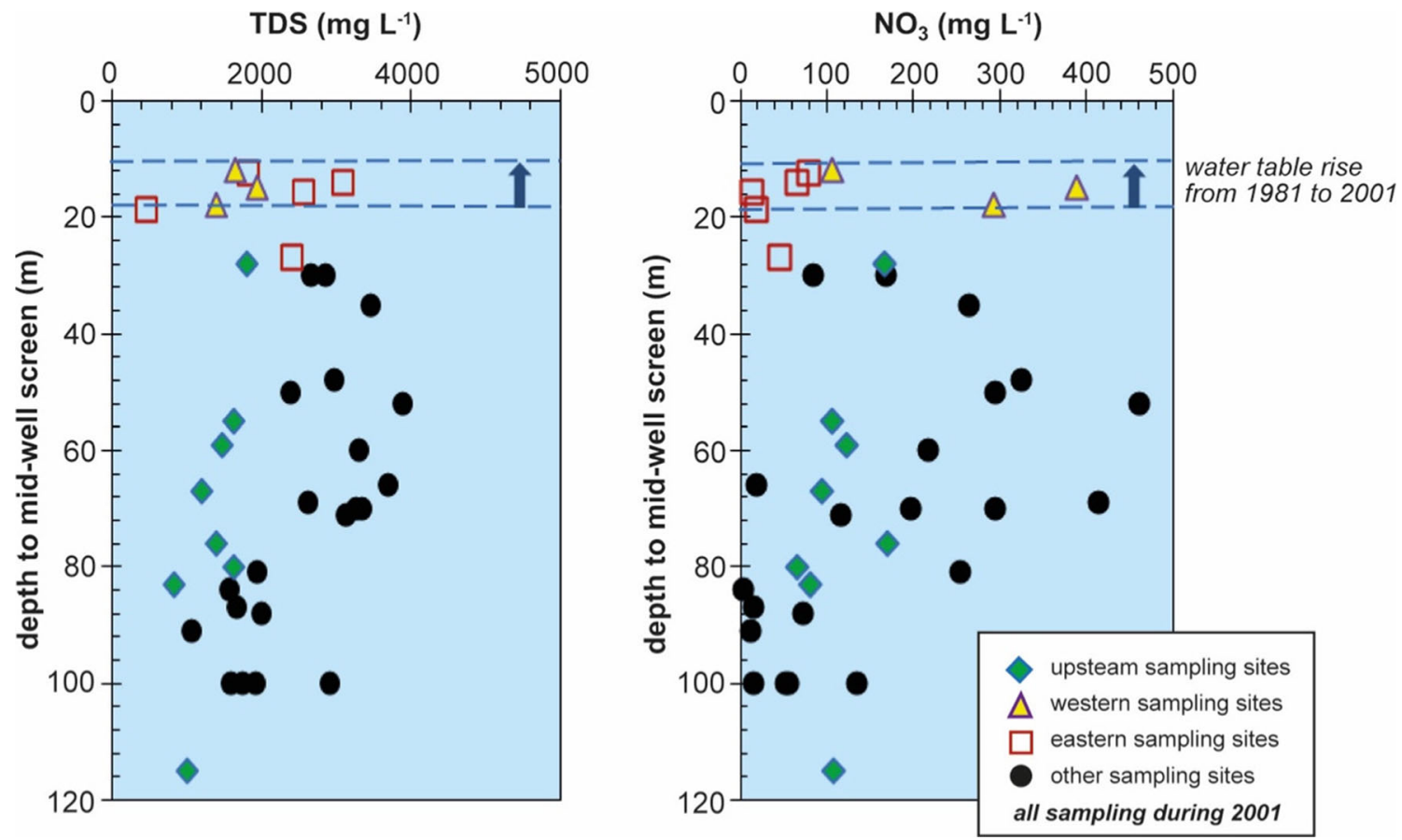

Fig. 4 Groundwater salinity and nitrate variation with depth in the upper aquifer of the Campo de Dalias groundwater system 
salinisation in the upper aquifer and reduce abstraction from the deep aquifer:

- Taking every opportunity of managed recharge of surface run-off to the shallow aquifer during high-intensity rainfall episodes in the Sierra Gador

- Closing or partly grouting-up those waterwells considered to be most responsible for mobilising salinity from the underlying Pliocene aquitard

- Evaluating trade-offs between reducing the annual salt load in irrigation returns (and thus shallow groundwater salinity) and reducing cropping intensity and/or the proportion of intensively cropped land

- Optimising total $\mathrm{N}$ applications from organic manures, inorganic fertilisers and groundwater irrigation so as to reduce excessive $\mathrm{NH}_{4} / \mathrm{NO}_{3}$ leaching to shallow groundwater, which is not in the best interest of farmers themselves.

\section{Carrizal Aquifer, Mendoza, Argentina}

The Carrizal Aquifer underlies a sub-catchment of $240 \mathrm{~km}^{2}$ in an arid Andean palaeo-valley between the present courses of the Mendoza and Tununyan rivers (Fig. 5), with an annual rainfall of about $180 \mathrm{~mm}$ (Llop 2002). It currently includes about $140 \mathrm{~km}^{2}$ of irrigated land, mainly using waterwells and pressurised systems, but some surface-water irrigation is also practiced over $40 \%$ of the area within the Mendoza RiverLujan Sur canal system in the north and along the Arroyo Carrizal (which receives natural aquifer discharge) in the south-east. Most of the valley is filled with thick Quaternary piedmont alluvial deposits, forming an important unconfined aquifer with a deep water table (10-70 m) and high permeability (20-100 m/day), but which thins abruptly southeastwards against a neotectonic feature (Fig. 6).

In the 'natural condition', groundwater recharge largely originated as seepage from a $10 \mathrm{~km}$ stretch of the Mendoza riverbed (above the Dique Cipoletti), and aquifer discharge (of about $40 \mathrm{Mm}^{3} / \mathrm{a}$ ) created the Arroyo Carrizal. During 19791999, the rate of this riverbed recharge (determined by differential gauging) varied widely with riverflow regime in the range $50-130 \mathrm{Mm}^{3} / \mathrm{a}$, but is thought to have averaged about $85 \mathrm{Mm}^{3} / \mathrm{a}$. A further $40 \mathrm{Mm}^{3} / \mathrm{a}$ of the river water, diverted to Lujan Sur for canal-irrigation, was estimated also to end up as groundwater recharge. However, important changes in the hydrological regime were introduced from around 2000 (Foster and Garduno 2006) by:

\section{$\mathbf{N}$}

$\mathbf{S}$

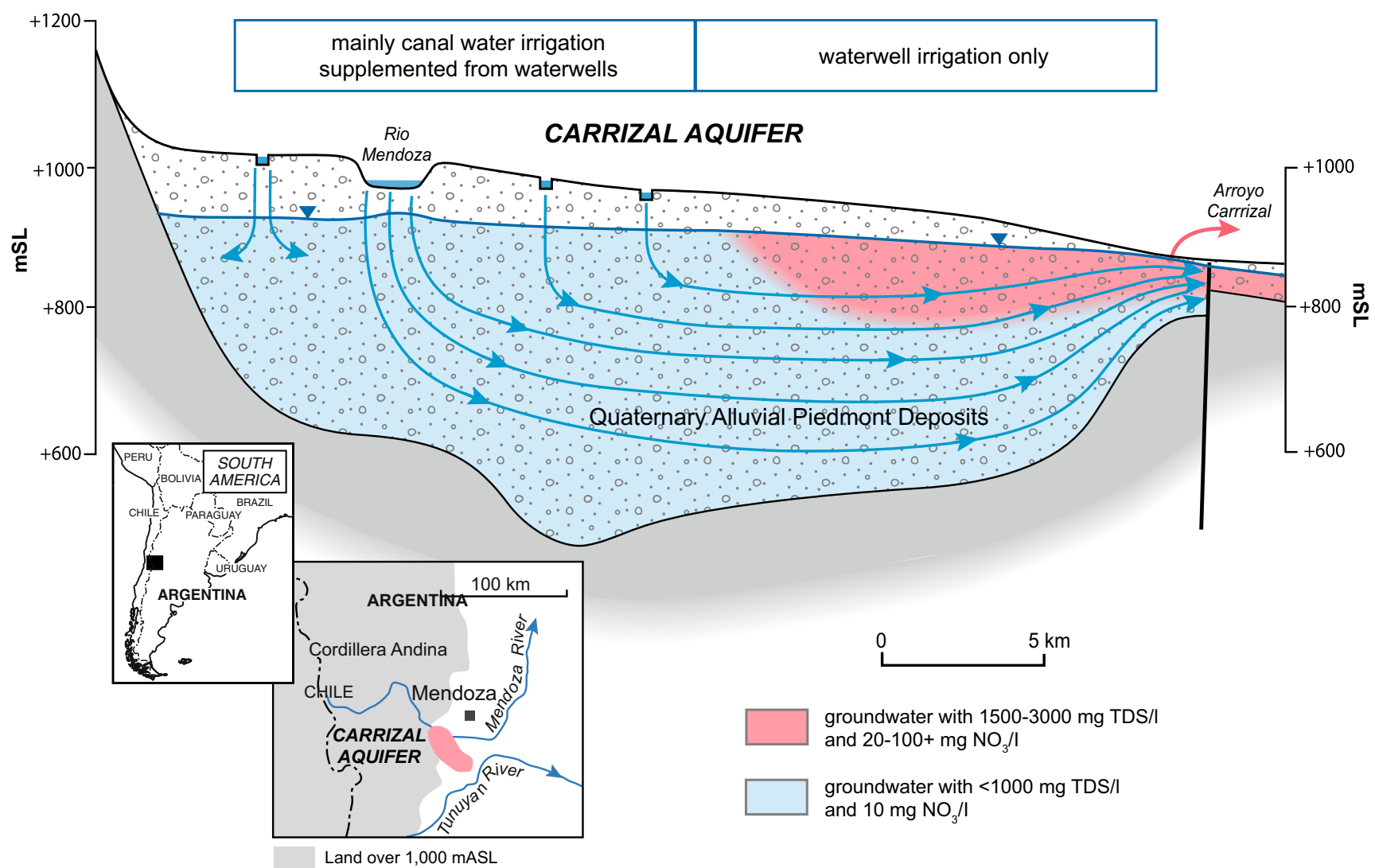

Fig. 5 Hydrogeological cross-section and location map of the Carrizal Aquifer of Mendoza, Argentina 


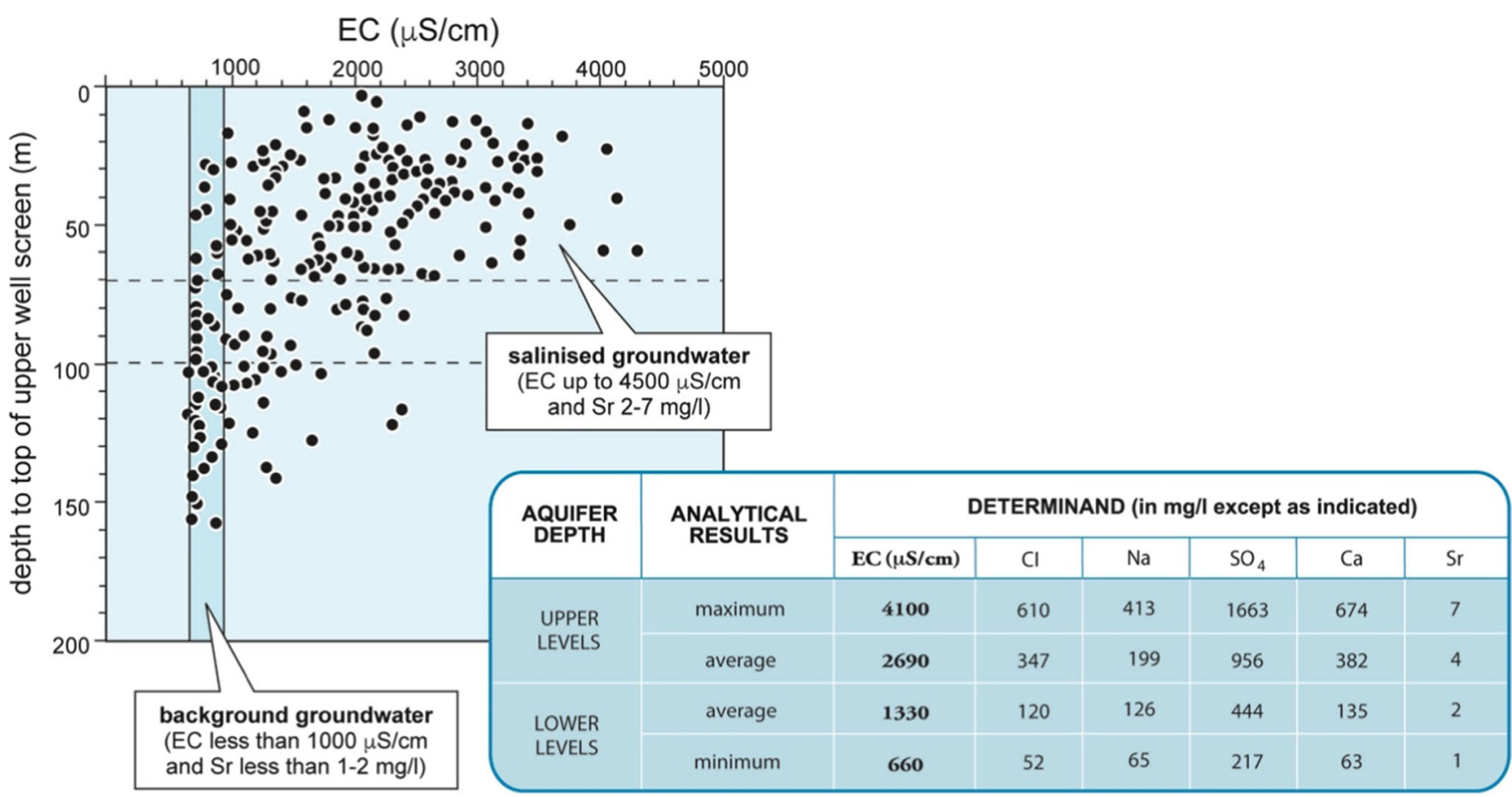

Fig. 6 Groundwater salinity variation with depth in waterwells of the Carrizal Aquifer in the Ugarteche area during 2003-2004

- Upstream construction of the Potrerillos Dam and hydropower plant - radically changing the riverflow regime and reducing by $60 \%$ the riverbed length over which recharge occurs continuously, although increased unit seepage rates will occur from 'clear water infiltration'

- Progressive reduction in irrigation returns to groundwater-related to growth in the irrigated area with pressurised water application.

After the first waterwells were drilled in the 1950s, the Carrizal Valley became a horticultural area, but during the 1990s it was discovered to have exceptional soil and a microclimate for export-quality viticulture and fruit production. This created a consumptive water demand on all cultivated land of 3-4 mm/day during October-March (totaling 700 $800 \mathrm{~mm} / \mathrm{a}$ ), which was met from a major expansion of groundwater use (with more than 1,000 waterwells having been drilled). Modern irrigated agriculture systems were installed that utilized pressurised ferti-irrigation, anti-hail nets and minimal tillage with glyphosate herbicides and copper fungicides. Today agricultural land prices on the western flanks of this broad valley are high (from US\$ $30-50,000 /$ ha for land with productive vines and water use rights, to US\$ 4,000/ha for uncultivated dryland). This is putting tremendous pressure on the groundwater resource administration, since there are now 600-700 active production waterwells.

Intensive groundwater development, with competition for available resources amongst the many waterwell users, has given rise to concern about falling groundwater levels and increasing groundwater salinity in some areas. For this reason, a 'groundwater use restriction zone' was declared in 1997, with the aim of constraining the expansion of the irrigated area, stabilising groundwater levels and maintaining outflow to the Arroyo Carrizal. The elaboration of a MODFLOW numerical aquifer model suggested a long-term equilibrium of the groundwater system in 2000 , but with significant withdrawals from aquifer storage (25-60 $\left.\mathrm{Mm}^{3} / \mathrm{a}\right)$ to support abstraction in periods of below average riverflow. The model provided a physical basis for assessing the aquifer salt balance and groundwater salinity problem.

Groundwater quality surveys during 2003-2005 (Alvarez and Villaalba 2003; Foster and Garduno 2006) revealed that with increasing distance from the Mendoza River there existed:

- Overall salinity stratification with elevated EC of 2,600$4,400 \mu \mathrm{S} / \mathrm{cm}(1,690-2,860 \mathrm{TDS} \mathrm{mg} / \mathrm{L})$ down to $70 \mathrm{~m}$ below ground level (bgl), but with deeper screen intakes recording 1,000-2,400 $\mu \mathrm{S} / \mathrm{cm}(650-1,560 \mathrm{TDS} \mathrm{mg} / \mathrm{L}$; Figs. 5 and 6)

- A major increase in salinity since the 1960 s, when shallow and deep groundwater was found to have $\mathrm{EC}=1,800$ and $1,000 \mu \mathrm{S} / \mathrm{cm}(1,170$ and $650 \mathrm{TDS} \mathrm{mg} / \mathrm{L})$ respectively during an early reconnaissance by the United Nations Development Proramme

- A similar distribution of major elements (such as $\mathrm{Na}, \mathrm{Cl}$, $\mathrm{Ca}, \mathrm{SO}_{4}, \mathrm{NO}_{3}$ and certain minor elements such as $\mathrm{Li}, \mathrm{Sr}$ ), with for example $\mathrm{NO}_{3}$ and $\mathrm{Cl}$ at levels of $20-60 \mathrm{mg} / \mathrm{L}$ and $150-750 \mathrm{mg} / \mathrm{L}$ in shallow groundwater compared to levels of $\mathrm{NO}_{3}<10 \mathrm{mg} / \mathrm{Land} \mathrm{Cl}<100 \mathrm{mg} / \mathrm{L}$ at depth. 
Increased groundwater salinity in the southeastern section of the valley has resulted in the substitution of onion and garlic cultivation for more profitable viticulture, with a corresponding fall in land values. The observed 20042005 distribution of groundwater salinity, accompanied by elevated anthropogenic nitrate, suggests that it can be primarily attributed to increasing salinisation of irrigation returns, consequent upon significant recirculation of salts through groundwater irrigation and the initial leaching of barren desert soils when first brought into irrigated cultivation. The process has been more marked given that natural groundwater residence times in this aquifer system are likely to be in excess of 100 years. Hydrocarbon exploitation in the general area could have led to some seepage of oilwell formation water (containing $\mathrm{Na}=$ $24,000 \mathrm{mg} / \mathrm{L}$ and $\mathrm{Cl}=39,000 \mathrm{mg} / \mathrm{L}$ ), but overall it does not appear that this has been a major factor in groundwater salinisation.

Certain specific additional groundwater management measures would appear worthy of detailed consideration to mitigate increasing groundwater salinisation:
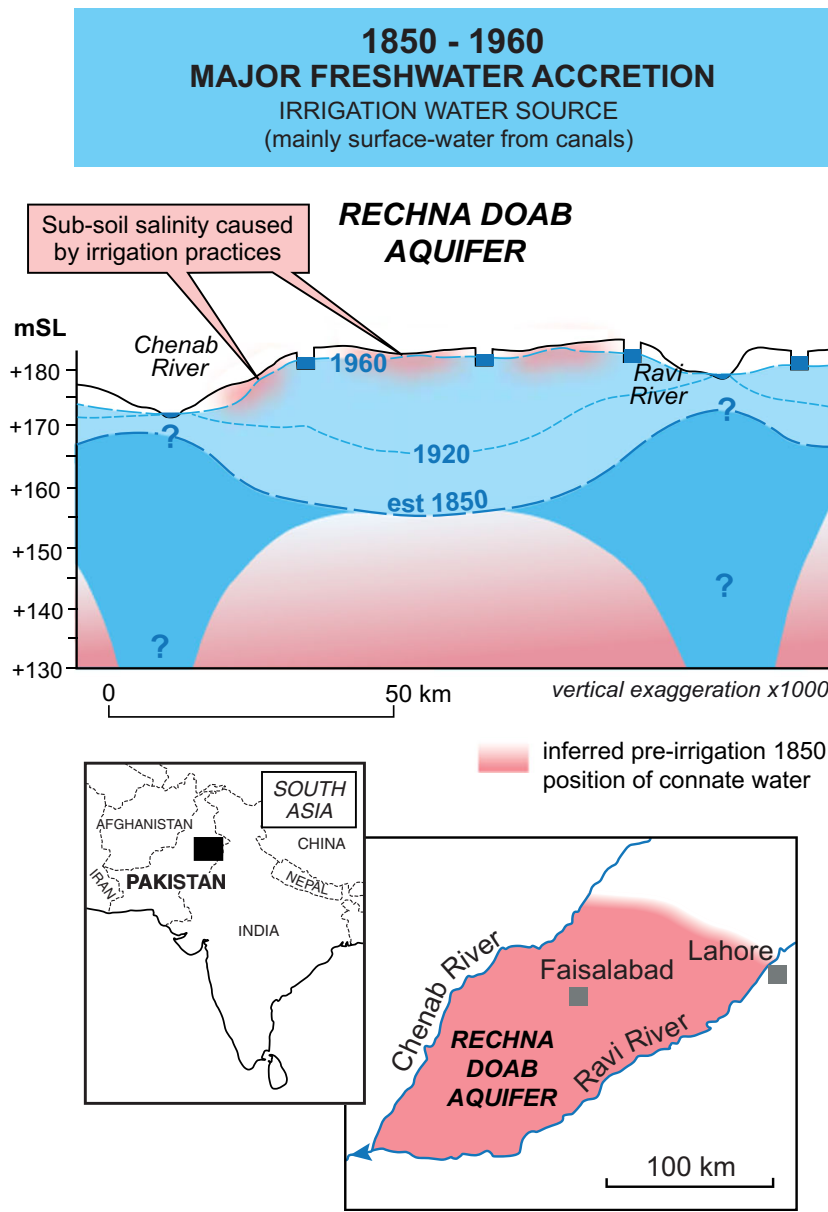

Fig. 7 Location map and long-term evolution of groundwater levels and salinity in the Rechna Doab of the Indus Plain aquifer system
- Diverting more water from the Mendoza River into the Carrizal Valley (during periods of peak flow) for managed aquifer recharge and continuing to constrain consumptive groundwater use.

- Licensing of replacement waterwells in areas where shallow groundwater is already salinized should be accompanied by a reduction of annual abstraction and appropriate waterwell construction.

- Some existing shallow saline groundwater can be used for cultivation of less-sensitive cash crops (like onions), where it is possible to mix it with lower-salinity groundwater, but this should still be subject to reducing annual abstraction.

\section{Rechna Doab, Punjab, Pakistan}

The Rechna Doab lies in the heart of the Indus Valley and occupies an area of $3,000 \mathrm{~km}^{2}$ between the Chenab and Ravi rivers (Fig. 7; Ahmed et al. 2005), with 2.3 Mha of arid land (receiving only $400 \mathrm{~mm} / \mathrm{a}$ average rainfall from the July-September mon-

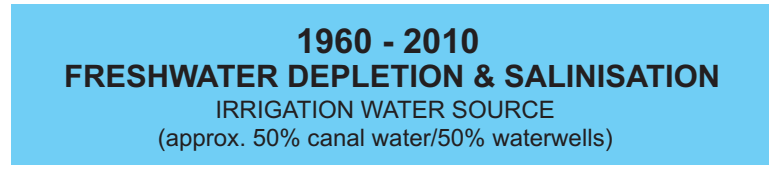

\section{RECHNA DOAB AQUIFER}

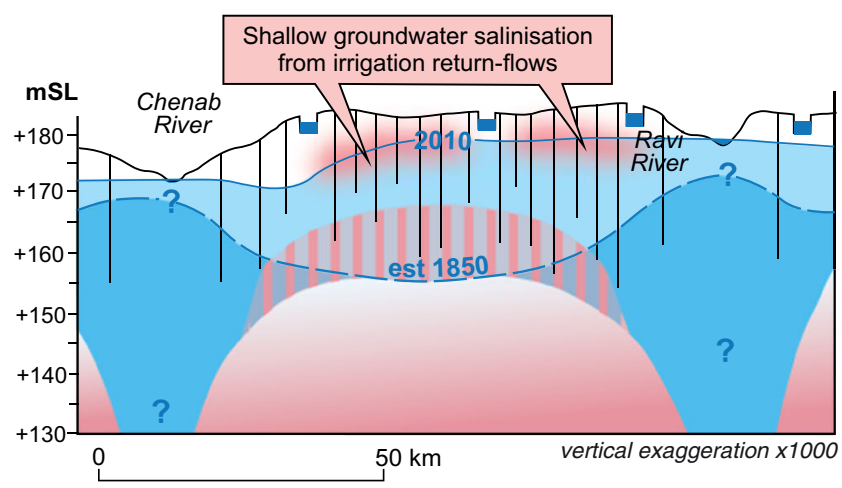

approximate rise of significantly saline groundwater as a result of intensive pumping of irrigation waterwells during 1960-2010 — there will also be some surficial salinisation (not shown) close to the irrigation canal network and in areas irrigated with groundwater alone 
soon) under irrigated double-cropping. Despite the aridity, in 2013 the entire Indus irrigation system of 14 Mha produced 9 Mtons of rice, 23 Mtons of wheat and $10 \mathrm{M}$ bales of cotton. Remarkably, for a system with some $57,000 \mathrm{~km}$ of irrigation canals, about $50 \%$ of total water-supply is today derived from waterwells, with more than 1 million being constructed in the last 30 years (Qureshi et al. 2008). Of great concern is the increase of farmed land affected by salinisation, which is impacting crop yields (Basharat and Tariq 2013). Part of the affected area exhibits sodic characteristics, with the hazard of breakdown of soil structure (Quirk and Schofield 1955).

To understand the groundwater salinisation processes, it is essential to appreciate the hydrologic evolution of this arid alluvial-outwash plain, which was originally underlain by saline water (Fig. 7) and into which fresh (low salinity) groundwater was introduced below riparian zones as a result of riverbed seepage. Progressively during 1850-1930, the construction of weir-controlled irrigation canals to reach land distant from the main rivers, led to widespread freshwater infiltration and formation of a continuous layer of groundwater across the low interfluves, with the main rivers changing from potentially 'losing' to 'gaining' groundwater. Critically also, major seepage from the irrigation canal network resulted in a rising water table that led to soil waterlogging and secondary soil salinisation in some zones. Currently, freshwater occurs to depths of $>100 \mathrm{~m}$ in a $20-30-\mathrm{km}$-wide zone beneath the river flood plains, but in the centre of the Rechna Doab the freshwater lens is only $10-20 \mathrm{~m}$ thick, and widely compromised by somewhat saline irrigation-return waters (Fig. 7).

In the 1950s, waterwell pumping was introduced to improve soil drainage and to mitigate soil sodic salinisationand it was also soon found useful to supplement irrigation water-supply during times of reduced surface-water availability. Subsequently there was a boom in privately drilled irrigation boreholes. The intensive utilisation of groundwater was critical to sustaining agricultural production during the 1998 2001 drought, and an associated lowering of the water table also further reduced the land area experiencing soil salinisation. However, severe water-table depletion in some areas, as a result of intensive irrigation waterwell pumping, caused up-coning of connate water and salt mobilisation to the land surface (van Steenbergen and Gohar 2005).

It is not straightforward to establish salinity trends because of the mixed nature of most samples taken from production tubewells, considerable lateral and vertical salinity variations, and the high cost of representative sampling (MacDonald et al. 2016). However, it is instructive to consider the issue from first principles. In low-lying flat alluvial terrain, underlain by thin fresh groundwater bodies, vertical flux (both downward and upward) tends to predominate over horizontal flow. It is thus valid to consider the water and salt balance. In such areas, irrigation canals deliver reasonable quality water for irrigation, with salinity usually in the range $180-250 \mathrm{mgTDS} / \mathrm{L}$. If typical canal water is taken as having $200 \mathrm{mgTDS} / \mathrm{L}$, when this water was first used for gravity-furrow irrigation, fractionation of its salt content will have occurred, and if $40 \%$ of the applied irrigation lamina infiltrated to shallow groundwater, this recharge would have contained $500 \mathrm{TDSmg} / \mathrm{L}$. Decades later, when supplementary irrigation with shallow groundwater became established, and provided say 50\% of the total annual irrigation lamina, then soil fractionation would have generated an irrigation water return to groundwater containing $875 \mathrm{mgTDS} / \mathrm{L}$. Subsequently, year-on-year, this process would inevitably lead to continuously rising groundwater salinity, eventually to exceed the FAO-UN guideline level of 1,500 $\mathrm{mgTDS} / \mathrm{L}$ (above which negative impacts on crop yields must be anticipated).

Certain measures can help reduce the salinisation trend of shallow groundwater in given areas such as a high level of direct canal seepage, a reduced proportion of conjunctive groundwater use or an episode of land-surface flooding. However, in practice, so-called (shallow) 'skimming waterwells', whilst normally providing the lowest-salinity option in the short-term for irrigation, will not mitigate the longerterm groundwater salinity problem, since their contained salts will be recycled to the shallow aquifer. Other factors could actually further steepen the rising salinity trend, including:

- Drilling deeper irrigation tubewells. While initially this may provide a groundwater supply of lower TDS, it runs a high risk of up-coning connate water.

- Improving field irrigation efficiency. As regards groundwater, this amounts simply to delaying impacts by reducing irrigation returns whilst increasing their salinity.

- Aeolian salt deposition. In arid climates there exists the possibility of occasional dust storms with winds capable of transporting particles of salty soil (Shiga et al. 2011).

The groundwater resources of the Punjab have already proven to be of critical importance to the food security of Pakistan; however, sustaining this role and developing their full potential will require a more proactive and adaptive approach to waterresource management (Qureshi et al. 2008). Central to this strategy will be that decisions on the lining of irrigation canals, and procedures for canal-water allocation and diversion entitlements, must take account of local groundwater conditions. There is also likely to be a periodic need to remove some salt load completely from various parts of the land-groundwater system (with appropriate safe disposal), as an additional element of integrated management. This will need to be compensated by increased use of surface water for gravity irrigation in the corresponding areas at times of excess riverflow, such that some dilution of existing groundwater salinity can be achieved. It will also be necessary to address the problem of mobilisation of connate groundwater, especially on the interfluves, requiring allocation and delivery of increased canal flows and reduction of waterwell depths and pumping rates. 
There is also a pressing need to undertake applied hydrogeological research (using geophysical survey, isotopic techniques, other tracers, hydrochemical analyses and numerical modeling) to determine the three-dimensional groundwater flow dynamics and quality genesis with more confidence. This would help elucidate temporal trends in groundwater salinity from the large quantity of historic monitoring data of mediocre quality. In parallel, it will be essential to strengthen the groundwater-monitoring infrastructure to enable the benefits of water-resource-management measures to be critically assessed,

\section{Land and water management options}

The persistence and complexity of the problems arising in all cases of groundwater recharge salinisation from irrigated agriculture is such that they can only be properly addressed through carefully planned integrated management of land, surface and groundwater resources. The implementation of essential management measures will require awareness raising, institutional change and capacity building - and it will only be after improved surface-water and groundwater management is in place, that measures to improve soil salinity and fertility will accrue and the long-term benefits of more sustainable, higher-yielding, agricultural cropping will be assured.

Where the water table is relatively shallow and significant aquifer throughflow is conserved, it is likely that shallow groundwater salinity will be drained from the aquifer by natural discharge or can be promoted by engineered drainage; however, in situations with deeper water tables, this will not be the case. Moreover, in situations with heavy groundwater pumping, the aquifer system will often be found to be the 'ultimate sink' for salinity accumulation. In such circumstances, more complex measures will be needed to 'freshen up' the groundwater system such as:

- Reducing the overall consumptive use of groundwater by substituting more surface-water irrigation or down-sizing the groundwater-irrigated area

- Increasing the rate of freshwater recharge, by making excess flows in any main irrigation canals available for this purpose and/or capturing local storm-water run-off to recharge lagoons.

These investments will require a staged approach with detailed shallow groundwater monitoring to judge their cost-effectiveness. Other management measures that will need to be considered include:

- Reducing annual cropping intensity (by eliminating crops of lower market value) so as to reduce the annual salt load generated by soil evapotranspiration processes
- Reducing the proportion of cropped land that is irrigated, whilst ensuring the highest possible economic return on those crops still cultivated

- Constraining groundwater abstraction to prevent aquifer water levels from falling below the level required for 'natural discharge', such that throughflow and drainage are maintained to avoid progressive salt accumulation in the groundwater systems.

A high priority for water resource agencies should be to provide incentives for farmers to maximize opportunities to supplement groundwater recharge from streambeds and soakaway-drains on their land. Such additional recharge will provide valuable dilution of saline (and nutrient rich) recharge from irrigated agricultural land.

\section{General conclusions}

1. The case profiles presented in this report reveal that the salinisation of groundwater recharge from intensive agricultural cropping using waterwell irrigation is a gradual but insidious phenomenon under more arid climatic conditions, whose management poses complex and costly challenges.

2. The phenomenon of groundwater recharge salinisation is not related to soil waterlogging and phreatic salinisation, since it has been demonstrated to be occurring where the water table is $5-50 \mathrm{~m}$ deep (although the process will also be occurring on alluvial plains of low relief).

3. Water resource agencies (in collaboration with their agricultural counterparts) need to evaluate salt balances (in addition to those for water and nutrients) periodically at aquifer sub-catchment level, to assess the risk of serious salinisation of groundwater recharge and to guide management interventions.

4. Improved integration of land and water management by agricultural and water resource agencies is a pressing need to specify, implement and refine mitigation measures for the control of the salinisation of groundwater recharge.

Acknowledgements The first author wishes to acknowledge past discussion of the processes of groundwater salinisation and options for their management in the context of the field areas presented in the report with the following: Amilcar Alvarez and Hector Garduño with respect to Mendoza, Argentina, and Mohammed Basharat and Frank van Steenbergen with respect to Punjab, Pakistan. He also thanks Chris Perry for a long-term sustained dialogue on the impacts of irrigated agriculture on groundwater, Antonio Pulido-Bosch (a co-author of this report) for many valuable interchanges down-the-years on groundwater irrigation issues, John Barker for valued advice on approaches to analytical modelling of the groundwater recharge salinisation process, and Gill Tyson for her excellent work improving the illustrations in this report.

Funding information Part of the survey work described in the field casehistory areas was supported by funding from the Junta de Andalucia (Almeria, Spain), the World Bank GW-MATE Programme (Mendoza, 
Argentina) and the UK Department for International Development (Rechna Doab, Pakistan).

Open Access This article is distributed under the terms of the Creative Commons Attribution 4.0 International License (http:// creativecommons.org/licenses/by/4.0/), which permits unrestricted use, distribution, and reproduction in any medium, provided you give appropriate credit to the original author(s) and the source, provide a link to the Creative Commons license, and indicate if changes were made.

\section{References}

Ahmed M, Bastiaanssen WGM, Feddes PA (2005) A new technique to estimate net groundwater use across large irrigated areas by combining remote sensing and water balance approaches. Hydrogeol $\mathrm{J}$ 13:653-664

Alvarez A, Villaalba JA (2003) Estudio del proceso de salinizacion de acuiferos en la zona este del Oasis Norte de Mendoza: avance en hidroquimica [Study of the salinisation process of aquifers in the eastern zone of the Northern Mendoza Oasis: advances in hydrochemistry]. INA-CRA Informe Tecnico 34, CRA, Mendoza, Argentina

Basharat M, Tariq A (2013) Long-term groundwater quality and saline intrusion assessment in an irrigated environment: a case study of the aquifer under the LBCD irrigation system. Irrig Drain 62:510-523

Bouhlassa S, Ammary B, Pare S, Safsaf N (2016) Integrating variations in the soil chloride profile and evaporativity for in-situ estimation of evaporation in arid zones: an application in south-eastern Morocco. Hydrogeol J 24:1699-1706

Diaz-Puga MA, Vallejos A, Sola F, Daniele L, Molina L, Pulido-Bosch A (2016) Groundwater flow and residence time in a karst aquifer using ion and isotope characterization. Int J Environ Sci Technol 13:25792596

Edmunds WM, Tyler SW (2002) Unsaturated zones as archives of past climates: towards a new proxy for continental regions. Hydrogeol J 10:216-228

Foster S, Cherlet J (2014) The link between land-use and groundwater: governance provisions and management strategies to secure a 'sustainable harvest'. GWP Perspectives Paper, Global Water Partnership, Stockholm

Foster S, Garduno H (2006) Integrated approaches to groundwater resource conservation in the Mendoza aquifers of Argentina. GWMATE Case Profile Collection 6, World Bank, Washington, DC

Foster SSD, Perry CP (2009) Improving groundwater resource accounting in irrigated areas: a pre-requisite for promoting sustainable use. Hydrogeol J 18:291-294

Foster S, Shah T (2012) Groundwater resources and irrigated agriculture: making a beneficial relation more sustainable. GWP Perspectives Paper, Global Water Partnership, Stockholm

Foster S, Chilton J, Moench M, Cardy F, Schiffler M (2000) Groundwater in rural development: facing the challenges of supply and resource sustainability. World Bank Technical Paper 463, World Bank, Washington, DC

Foster S, Tuinhof A, Kemper K, Garduno H, Nanni M (2002) Groundwater management strategies: facets of the integrated approach. GW-MATE Briefing Note 3, World Bank, Washington, DC

Garduno H, Foster S (2010) Sustainable groundwater irrigation: approaches to reconciling demand with resources. GW-MATE Strategic Overview Series 4, World Bank, Washington, DC

Hillel D, Braimoh AK, Vlek PLG (2008) Soil degradation under irrigation. In: Land use and soil resources. Springer, Dordrecht, The Netherlands
Jimenez-Martinez J, Skaggs T H, van Genuchten M T, Candela L (2009) A root zone modelling approach to estimating groundwater recharge from irrigated areas. J Hydrol 367: 138-149

Leduc C, Favreau G, Schroeter P (2001) Long-term rise in the Sahelian water-table: the continental terminal in South-West Niger. J Hydrol 243:43-54

Llop A (2002) Guia sobre la salinizacion del agua subterranean en el Este Mendocino [Guide to the salinisation of groundwater in Eastern Mendoza Province]. INA-CELAA, Mendoza, Argentina

MacDonald AM, Bonsor HC, Ahmed KM, Burgess WG, Basharat M, Calow RC, Dixit A, Foster SSD, Gopal K, Lapworth DJ, Lark RM, Moench M, Mukherjee A, Rao MS, Shamsudduha M, Smith L, Taylor RG, Tucker J, van Steenbergen F, Yadav SK (2016) Groundwater quality and depletion in the Indo-Gangetic Basin mapped from in-situ observations. Nat Geosci 9:762-766

Molina L, Sanchez-Martos F, Daniele L, Vallejos A, Pulido-Bosch A (2015) Interaction of aquifer-wetland in a zone of intensive agriculture: the case of Campo de Dalias (Almeria, SE Spain). Environ Geol 73:2869-2880

Ó Dochartaigh BR, MacDonald AM, Darling WG, Hughes AG, Li JX, Shi LA (2010) Determining groundwater degradation from irrigation in desert-marginal northern China. Hydrogeol J 18:1939-1952

Pulido-Bosch A (2005) Recarga en la Sierra de Gador e hidrogeoquimica de los acuiferos del Campo de Dalias [Recharge in the Sierra de Gador and hydrogeochemistry of the Campo de Dalias aquifers]. Report, Cajmar Experimental Station, Almeria, Argentinia

Pulido-Bosch A, Bensi S, Molina L, Vallejos A, Calaforra JM, PulidoLeboeuf P (2000) Nitrates as indicators of aquifer interconnection: application to the Campo de Dalias (SE-Spain). Environ Geol 39: 791-799

Quirk JP, Schofield RK (1955) The effect of electrolyte concentration on soil permeability. J Soil Res 6:163-178

Qureshi AS, McCornick PG, Qadir M, Aslam Z (2008) Managing salinization and waterlogging in the Indus Basin of Pakistan. Agric Water Manag 95:1-10

Rengasamy P, Marchuk A (2011) The cation ration of soil structural stability (CROSS). Soil Res 49:280-285

Rhoades JD, Kandiah A, Marshall AM (1992) The use of saline waters for crop production. FAO Irrigation and Drainage Paper 48, FAO, Rome

Scanlon SR, Jolly I, Sophocleous M, Zhang L (2007) Global impacts of conversions from natural to agricultural ecosystems on water resources: quantity versus quality. Water Resour Res 43:W03437

Seibert S, Burke J, Faures JM, Frenken K, Hoogeveen J, Doll P, Portmann FT (2010) Groundwater use for irrigation: a global inventory. Hydrol Earth Syst Sci 14:1863-1880

Shani U, Dudley LM (2001) Field studies of crop response to water and salt stress. Soil Sci Soc Am J 65:1522-1528

Shiga Y, Greene RSB, Scott KM, Stelcer E (2011) Recognising terrestrially-derived salt $(\mathrm{NaCl})$ in South-East Australia dust. Aeolian Res 2:215-220

van Steenbergen F, Gohar S (2005) World Bank Pakistan water resources assistance strategy. Background Paper 11, World Bank, Islamabad, Pakistan

Thompson R, Martinez C, Gallardo M (2006) Management factors contributing to nitrate leaching loss from a greenhouse-based intensive vegetable production system. Acta Hortic 700:179-184

Thompson R, Danielle L, Gallardo M, Pulido-Bosch A (2013) Stable isotope analysis to determine sources of nitrate from a vegetable production system in aquifer and drainage water. In: Proceedings of the international workshop 'Nitrogen, Environment and Vegetables', Turin, Italy, April 2013, pp 65-66

Vallejos A, Pulido-Bosch A, Martin-Rosales W, Calvache ML (1997) Contribution of environmental isotopes to the understanding of complex hydrologic systems: a case study of the Sierra de Gádor, SE Spain. Earth Surf Process Landforms 22:1157-1168 